\title{
Linking microbial heterotrophic activity and sediment lithology in oxic, oligotrophic sub-seafloor sediments of the North Atlantic Ocean
}

\author{
Aude Picard ${ }^{1,2}$ and Timothy G. Ferdelman ${ }^{1,2}$ \\ 1 Department of Biogeochemistry, Max Planck Institute for Marine Microbiology, Bremen, Germany \\ ${ }^{2}$ MARUM - Center for Marine Environmental Sciences, Bremen, Germany
}

\section{Edited by:}

Axel Schippers, Federal Institute for Geosciences and Natural Resources (BGR), Germany

\section{Reviewed by:}

Jens Kallmeyer, University of Potsdam, Germany

Gordon Webster, Cardiff University, UK

\section{*Correspondence:}

Aude Picard, Geomicrobiology, Center for Applied Geoscience Eberhard Karls University Tübingen, Sigwartstrasse 10, 72076 Tübingen, Germany.

e-mail: aude.picard@uni-tuebingen.de
Microbial heterotrophic activity was investigated in oxic sub-seafloor sediments at North Pond, a sediment pond situated at $23^{\circ} \mathrm{N}$ on the western flank of the Mid-Atlantic Ridge. The North Pond sediments underlie the oligotrophic North Atlantic Gyre at 4580-m water depth and cover a 7-8 million-year-old basaltic crust aquifer through which seawater flows. Discrete samples for experimentation were obtained from up to $\sim 9 \mathrm{~m}$-long gravity cores taken at 14 stations in the North Pond area. Potential respiration rates were determined in sediment slurries incubated under aerobic conditions with ${ }^{14} \mathrm{C}$-acetate. Microbial heterotrophic activity, as defined by oxidation of acetate to $\mathrm{CO}_{2}$ (with $\mathrm{O}_{2}$ as electron acceptor), was detected in all 14 stations and all depths sampled. Potential respiration rates were generally low $\left(<0.2 \mathrm{nmol}\right.$ of respired acetate $\left.\mathrm{cm}^{-3} \mathrm{~d}^{-1}\right)$ in the sediment, but indicate that microbial heterotrophic activity occurs in deep-sea, oxic, sub-seafloor sediments. Furthermore, discernable differences in activity existed between sites and within given depth profiles. At seven stations, activity was increased by several orders of magnitude at depth (up to $\sim 12 \mathrm{nmol}$ of acetate respired $\mathrm{cm}^{-3} \mathrm{~d}^{-1}$ ). We attempted to correlate the measures of activity with high-resolution color and element stratigraphy. Increased activities at certain depths may be correlated to variations in the sediment geology, i.e., to the presence of dark clay-rich layers, of sandy layers, or within clay-rich horizons presumably overlying basalts. This would suggest that the distribution of microbial heterotrophic activity in deeply buried sediments may be linked to specific lithologies. Nevertheless, high-resolution microbial examination at the level currently enjoyed by sedimentologists will be required to fully explore this link.

Keywords: microbial activity, heterotrophy, deep biosphere, oxic, marine sediment

\section{INTRODUCTION}

The mineralization of organic matter in marine sediments is governed by microbial metabolism. In the deep subsurface ( $>1.5 \mathrm{mbsf}$ ) of marine sediments, sulfate reduction, methanogenesis, and fermentation are considered to be the main metabolic activities responsible for the degradation of organic matter to small organic acids and $\mathrm{CO}_{2}$ (e.g., Parkes et al., 2000; D'hondt et al., 2002). However, since most sub-seafloor sediments considered in previous studies underlie productive coastal or upwelling areas, the microbial processes reflect the consequences of a high organic carbon flux to the seafloor, in which oxygen is rapidly depleted (D'hondt et al., 2009). Oligotrophic regions occur in the subtropical ocean gyres that represent a major part of the world's ocean where the organic matter flux to the sediments is low, leading to deep oxygen penetration depths of tens of centimeters or more (Murray and Grundmanis, 1980). At the extreme, penetration depths of dissolved oxygen in the South Pacific Gyre sediments reached up to $9 \mathrm{~m}$ (D'hondt et al., 2009; Fischer et al., 2009).

Deep penetration of oxygen in sediments of the Atlantic Ocean to $\sim 9$ meters have also been shown in sediments contained in ponded basins on the flanks of the North Mid-Atlantic Ridge (MAR), in the so-named North Pond (Cruise report MSM 11/1). North Pond is an isolated region of ponded sediment situated at $\sim 100 \mathrm{~km}$ west of the rift valley of the MAR and $\sim 110 \mathrm{~km}$ south of the Kane fracture zone $\left(22^{\circ} 46^{\prime} \mathrm{N}\right.$ and $46^{\circ} 06^{\prime} \mathrm{W}$; e.g., Hussong et al., 1979; Purdy et al., 1979). It is a large pond $(\sim 13 \mathrm{~km} \mathrm{~N}-\mathrm{S}$ and $\sim 7 \mathrm{~km} \mathrm{E}-\mathrm{W}$ ) and lies below a low-productivity 4580 -m water column. The sediment at North Pond can reach up to $300 \mathrm{~m}$ thickness and overlies a young basaltic active crust $(7-8 \mathrm{Ma})$ through which vigorous lateral flow of cold seawater has been proposed to take place (Langseth et al., 1984).

We investigated microbial heterotrophic activity in sediment cores recovered at North Pond. Studies of microbial life in deepoxic sediments are rare (D'hondt et al., 2009), and no measurements of experimentally determined, potential respiration rates have been reported yet in sub-seafloor sediment in which oxygen is penetrating several meters deep. We used ${ }^{14} \mathrm{C}$-acetate in the deep-oxic sediments from North Pond for this purpose as acetate has been proven to be well-suited to estimate potential respiration and uptake rates of organic molecules in subsurface environments 
(e.g., Wirsen and Jannasch, 1974; Phelps et al., 1989; Fredrickson et al., 1997). In the case of anoxic sediments the changes in pore water chemistry usually help to target the zones where specific types of microbial activity can be expected (i.e., sulfate-methane transition zones). At North Pond, the sampled sediments were oxic throughout, thus the sampling strategy was different. To gain an overview of the potential respiration rates, which were expected to be low and decreasing with depth at all stations, we sampled the oxic sediment with a regular spacing along the length of gravity cores obtained from North Pond. Occasionally, distinct layers, such as sandy, clay-rich, dark layers, were also sampled.

The goal of the microbial heterotrophic activity measurements was to compare potential respiration rates at different stations over a small area and investigate correlations between activity profiles and geological features. We present profiles of potential microbial heterotrophic activity in deep-sea, deep-oxic sub-seafloor sediments, and examine these rates in conjunction with respect to variations in sediment lithology.

\section{MATERIALS AND METHODS SEDIMENT COLLECTION}

The North Pond area was visited during cruise MSM 11/1 on R/V Maria S. Merian in February-March 2009. Sediment cores were taken at 14 stations using a gravity corer (Table 1, Figure 1). Cores were split in two halves and labeled following the GeoB system of the University of Bremen. One half was kept intact for scanning analyses (archive half) while the other half was sampled for multiple purposes (work half). Sediment for activity measurements was sampled aerobically every meter. Additional samples were taken in specific cores when the sediment showed obvious lithological samples or color changes. Sediment was stored and transported at $4^{\circ} \mathrm{C}$. Pore water samples for acetate measurements were taken within hours after core retrieval using Rhizone soil moisture samplers (Rhizosphere Research Products, Wageningen, The Netherlands). The Rhizone consists of an inert porous polymertube with a length of $10 \mathrm{~cm}$ and a pore size of $0.1 \mathrm{~mm}$. Pore fluid is extracted by vacuum created with disposable $10 \mathrm{ml}$ syringes connected to the Rhizone, frozen and kept at $-20^{\circ} \mathrm{C}$ until analysis.

\section{PROKARYOTIC ACTIVITY MEASUREMENTS}

Sediment slurries were prepared with 1 volume of sediment for 4 volumes of oxic artificial seawater (ASW; Süß et al., 2004) and distributed into Eppendorf tubes for incubation ( $1 \mathrm{ml}$ slurry per tube). The potential respiration rates were estimated by measuring the production of ${ }^{14} \mathrm{CO}_{2}$ from the oxidation of ${ }^{14} \mathrm{C}$-acetate (sodium ${ }^{14} \mathrm{C}$-acetate, $5.8 \mu \mathrm{l}, 43 \mathrm{kBq}, 20 \mathrm{nmol}$, GE Healthcare Life Sciences, UK or sodium ${ }^{14} \mathrm{C}$-acetate, $1.16 \mu \mathrm{l}, 43 \mathrm{kBq}, 20 \mathrm{nmol}$, American RadioChemicals, Saint-Louis, MO, USA). Two living samples and one formaldehyde-treated sample ( $2 \% \mathrm{v} / \mathrm{v}$ final concentration, dead control) were prepared for each of three incubation periods ( 3,8 , and 15 days) and amended with the radiotracer. Samples were incubated at $4^{\circ} \mathrm{C}$ (close to the in situ temperature of $2.5^{\circ} \mathrm{C}$ ). Incubation was terminated by pouring the $1 \mathrm{ml}$ slurry into $9 \mathrm{ml}$ of $2.5 \% \mathrm{NaOH}$. Measurement of ${ }^{14} \mathrm{CO}_{2}$ (diffusion method) was performed as described in Treude et al. (2003) with slight modifications. Samples in $\mathrm{NaOH}(5 \mathrm{ml})$ were transferred to $100-\mathrm{ml}$ glass vials with $5 \mathrm{ml}$ of $2.5 \% \mathrm{NaOH}$. A $6-\mathrm{ml}$ scintillation vial containing $1 \mathrm{ml}$ of beta-phenylethylamine and $1 \mathrm{ml}$ of $\mathrm{NaOH}$ $0.5 \mathrm{M}$ was fixed to the rubber stopper that closed the glass vial, hanging well above the sample to trap the ${ }^{14} \mathrm{CO}_{2}$ in the headspace. Samples were then acidified with $6 \mathrm{ml}$ of $\mathrm{HCl} 6 \mathrm{~N}$ to release the $\mathrm{CO}_{2}$ in the headspace and gently shaken $(88 \mathrm{rpm})$ for at least $4 \mathrm{~h}$ at room temperature. A scintillation cocktail (ScintiGold, Perkin Elmer, USA) was added to the samples. Activity (in DPM) of the trapped ${ }^{14} \mathrm{CO}_{2}$ was measured using a liquid scintillation counter (Tri-Carb 2500TR or 2900TR, Packard, now Perkin Elmer, USA). Rates of acetate respiration were calculated using the following equation:

$R=\frac{{ }^{14} \mathrm{CO}_{2} \times\left[{ }^{14} \mathrm{C} \cdot \text { acetate }\right]}{{ }^{14} \mathrm{C} \cdot \text { acetate } \times v \times t}$

where $R$ is the rate of acetate respiration in the sediment (in nanomole $\left.\mathrm{cm}^{-3} \mathrm{~d}^{-1}\right),{ }^{14} \mathrm{CO}_{2}$ is the activity of the produced carbon

Table 1 | Stations of the MSM 11/1 cruise: sampling positions, water depth, sediment depth recovered, depths of samples for activity experiments.

\begin{tabular}{|c|c|c|c|c|c|}
\hline Station (GeoB) & Latitude (N) & Longitude (W) & Water depth (m) & Total sediment depth $(\mathrm{cm})$ & Number of samples for activity \\
\hline 13502 & $22^{\circ} 49,41^{\prime}$ & $46^{\circ} 3,23^{\prime}$ & 4250 & 847 & 10 \\
\hline 13504 & $22^{\circ} 49,89^{\prime}$ & $46^{\circ} 2,78^{\prime}$ & 4096 & 72 & 4 \\
\hline 13505 & $22^{\circ} 47,55^{\prime}$ & $46^{\circ} 7,40^{\prime}$ & 4402 & 76 & 2 \\
\hline 13506 & $22^{\circ} 48,36^{\prime}$ & $46^{\circ} 7,51^{\prime}$ & 4143 & 574 & 6 \\
\hline 13508 & $22^{\circ} 46,89^{\prime}$ & $46^{\circ} 6,59^{\prime}$ & 4475 & 344 & 4 \\
\hline 13509 & $22^{\circ} 47,47^{\prime}$ & $46^{\circ} 6,45^{\prime}$ & 4438 & 267 & 3 \\
\hline 13510 & $22^{\circ} 47,35^{\prime}$ & $46^{\circ} 6,44^{\prime}$ & 4448 & 515 & 6 \\
\hline 13511 & $22^{\circ} 47,12^{\prime}$ & $46^{\circ} 6,49^{\prime}$ & 4445 & 468 & 5 \\
\hline 13512 & $22^{\circ} 49,33^{\prime}$ & $46^{\circ} 6,45^{\prime}$ & 4200 & 516 & 5 \\
\hline
\end{tabular}




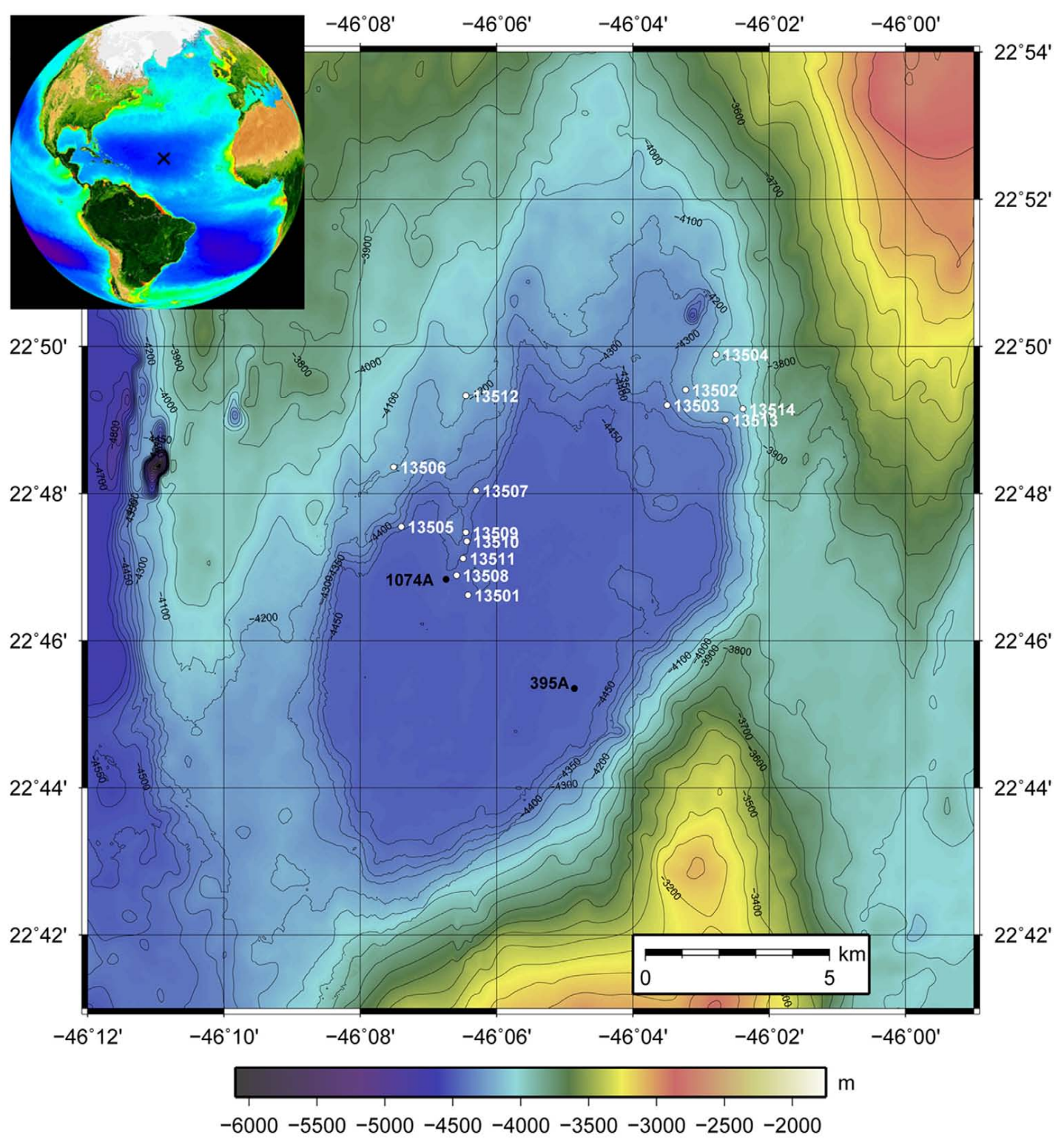

FIGURE 1 | Bathymetric map of North Pond. Stations are indicated with the white numbers (GeoB 13501-GeoB 13514). GeoB 13501 is the reference station situated near the center of the pond in the flat, deep center of the sediment pond. All others cores have been taken at shallower depths on the edges of the pond where sediment thicknesses are reduced. The inset shows the situation of North Pond in the Atlantic Ocean (generated on oceancolor.gsfc.nasa.gov/ SeaWiFS). dioxide in the living samples (in DPM) corrected by the activity (in DPM) in the dead samples, $\left[{ }^{14} \mathrm{C}\right.$-acetate $]$ is the concentration of acetate added as a tracer (in nmol), ${ }^{14} \mathrm{C}$-acetate is the activity of the tracer added (in DPM), $v$ is the volume of sediment (in $\mathrm{cm}^{3}$ ), and $t$ is the time of incubation (in d).

\section{MONITORING OF OXYGEN CONCENTRATION DURING SLURRY INCUBATION}

Oxygen concentration was monitored in one sediment sample to evaluate if the conditions remained oxic throughout the experiment. The sample was selected from core GeoB 13506
( $131.5 \mathrm{~cm}$ below the seafloor) and slurry was prepared as described above and transferred to a borosilicate glass vial without headspace. Incubation was performed at $4^{\circ} \mathrm{C}$. Non-labeled acetate was added at the same concentration than in the experiment with labeled acetate. Oxygen was measured during the incubation with a needle-type optical oxygen microsensor (PreSens Precision Sensing $\mathrm{GmBH}$, Germany). It consisted of a fiber optic cable mounted in a needle at the end of a 1-ml syringe. The needle was inserted into the borosilicate vial through a silicon septum. The sensor was extended for measurement into the sediment phase of the slurry. The microsensor readout was made using a Microx TX3 (PreSens 
Precision Sensing GmBH) micro-fiber optic oxygen transmitter. A two-point calibration using anoxic and air-saturated ASW at $4{ }^{\circ} \mathrm{C}$ was used.

\section{ACETATE MEASUREMENTS}

Concentrations of acetate (and other volatile fatty acids) were determined in pore water samples by high-performance liquid chromatography (HPLC) using the method of Albert and Martens (1997), as adapted by Finke and Jorgensen (2008). Pore water samples $(1 \mathrm{ml})$ were transferred into borosilicate glass vials (previously combusted at $480^{\circ} \mathrm{C}$ for $4 \mathrm{~h}$ ). Acids were derivatized with p-nitrophenyl hydrazine, eluted with ion-pairing solvents and separated by HPLC using a LiChrosphere $80 / 100$ column (Knauer, Berlin, Germany) at $25^{\circ} \mathrm{C}$. The presence of acids was determined by UV absorption at $400 \mathrm{~nm}$ with a UV/VIS detector (Linear). The chromatograms were analyzed using the commercially available software Chromstar (Bechenheim, Germany). Standard solutions containing known concentrations of lactate, acetate, formate, propionate, isobutyrate, and butyrate were used. The detection limit for acetate was at $3 \mu \mathrm{M}$.

\section{CORE ANALYSES}

Undisturbed, archive halves of the gravity core sections were stored at $4^{\circ} \mathrm{C}$ at the core repository of the University of Bremen (Germany) until analyzed in 2011. Nine sediment cores chosen for detailed core analysis were prepared for non-destructive highresolution digital, light, and $\mathrm{x}$-ray fluorescence scanning using stainless steel or glass blades to provide a smooth and regular surface.

\section{Digital imaging}

High-resolution digital images of the split cores were taken using the GEOTEK Geoscan-III color line scan camera (3 CCD device using $3 \times 1024$ pixel CCD arrays, RGB detectors) mounted on the rack of the GEOTEK Multi-Sensor Core Logger (MSCL) at the University of Bremen.

\section{Light reflectance}

The light reflectance $\left(\mathrm{L}^{*}\right)$ was measured at the surface of the split cores (covered with a thin film) using a Konica Minolta portable color spectrophotometer CM-2600d with diffuse illumination and $8^{\circ}$ viewing angle (University of Bremen). Measurements were done every $2 \mathrm{~cm}$ on an $8-\mathrm{mm}$ diameter area. The wavelength range of the instrument was $360-740 \mathrm{~nm}$. The instrument was calibrated using a white-calibration plate and a zero-calibration box.

\section{X-ray Fluorescence scanning}

$\mathrm{X}$-ray fluorescence (XRF) core scanner data were collected every $2 \mathrm{~cm}$ down-core (except for core 13504, every $1 \mathrm{~cm}$ down-core) over a $120 \mathrm{~mm}^{2}$ area and with a sampling time of $20 \mathrm{~s}$ directly at the split core surface of the archive half with the Avaatech XRF Core Scanner II at MARUM-University of Bremen. The split core surface was covered with a $4 \mu \mathrm{m}$ thin SPEX CertiPrepUltralene ${ }^{\circledR}$ foil to avoid contamination of the XRF measurement and desiccation of the sediment. The X-ray generator was an Oxford Instruments XTF5011 Rhodium X-ray tube 93057 set at an energy of $10 \mathrm{keV}$ and at a current of $0.2 \mathrm{~mA}$. The XRF data were acquired by a Canberra
X-PIPS Silicon Drift Detector (SDD, model SXD 15C-150-500) with $150 \mathrm{eV}$ X-ray resolution with a Canberra digital spectrum analyzer DAS 1000 as interface. Raw XRF spectra were processed using the WIN AXIL (Analysis of X-ray spectra by Iterative Least square) package from Canberra Eurisys.

\section{RESULTS}

\section{SITE DESCRIPTION AND SEDIMENT CHARACTERISTICS}

Fourteen gravity cores were taken during MSM 11/1 in water depths between 4040 and $4480 \mathrm{~m}$ (Table 1; Figure 1). Station 13501 is near the center of the pond at a water depth of $4480 \mathrm{~m}$ and served as a reference since it is in the deep, flat part of the pond with the greatest sediment thickness. Other stations were sampled where sediment thicknesses are reduced, at the N-E edge of the pond (GeoB13502, 13503, 13504, 13513, and 13514), at the N-W edge of the pond (GeoB13505, 13506, 13507, and 13512), and on a crest directed toward the center of the pond (GeoB13508, 13509, 13510 , and 13511). Slumps of sediments occur on the slopes, thus the sedimentary pile is reduced. We targeted the sediment-basalt interface at these stations.

The principal lithology at North Pond is yellowish-brown to brownish-yellow pelagic sediment, ranging from nannofossil ooze with variable amounts of clay and foraminifers to foraminifer rich sand to clay (Timofeev et al., 1979; Cruise report MSM 11/1). The presence of sharp, irregular bottom contacts, and normal graded bedding indicates that the sandy coarse-grained intervals are the result of gravity flows supplied from the surrounding slopes (e.g., in GeoB 13501, Figure 2). Sand layers are found only in cores retrieved from depths $>4300 \mathrm{~m}$ below sea level. At two sites, GeoB13504 (Figure 3) and GeoB13505, dense yellow to ochre clay was recovered. This clay ostensibly overlies basalt (Timofeev et al., 1979). The lower clay layer at GeoB13504 contained micrometersized fragments of basalt and glass. Mn micronodules within the nannofossil ooze, ranging from $<1$ to $3 \mathrm{~mm}$ in diameter, were identified in many cores.

Visible-light reflectance was measured at the surface of the archive core halves of nine selected stations and correlates well with the carbonate content of the sediment as established previously (Giosan et al., 2002; Rogerson et al., 2006). XRF provided semiquantitative measurements of light elements ( $\mathrm{Al}, \mathrm{Si}, \mathrm{K}, \mathrm{Ca}, \mathrm{Ti}, \mathrm{Mn}$, and $\mathrm{Fe}$ ) that can be used to evaluate their relative abundance along the cores. $\mathrm{Ca}$ is used to record carbonate content; $\mathrm{Ca} / \mathrm{Al}$ is used as an indicator of fine-grained sediments vs. coarse-grained sediments, thus the higher the ratio the coarser the grain size (Richter et al., 2006). GeoB13501 (Figure 2) and 13504 (Figure 3) contain the principal lithological features observed at North Pond during MSM 11/1 cruise and are therefore described here in details. Values of $L^{*}$ ranged from 40.27 to 64.25 in Core GeoB13501 (Figure 2); foraminifer sand layers at 257-261, 264-271, 538-546, 644-653, $702-713,742-764$, and $777-781 \mathrm{~cm}$ (yellow lines in Figure 2) correspond to $\mathrm{L}^{*}$ maxima and are further highlighted by peaks in the $\mathrm{Ca} / \mathrm{Al}$ ratio. The high $\mathrm{L}^{*}$ values are generally correlated with high Ca counts, which, in turn, correspond to a high carbonate content. The lowest L* values at 444 and $518 \mathrm{~cm}$ in GeoB13501 occur at dark layers richer in clay than the surrounding nannofossil ooze and correspond to low $\mathrm{Ca} / \mathrm{Al}$ ratios (gray lines in Figure 2). The presence of Mn micronodules at $\sim 440, \sim 580, \sim 675$, and $\sim 800 \mathrm{~cm}$ is 

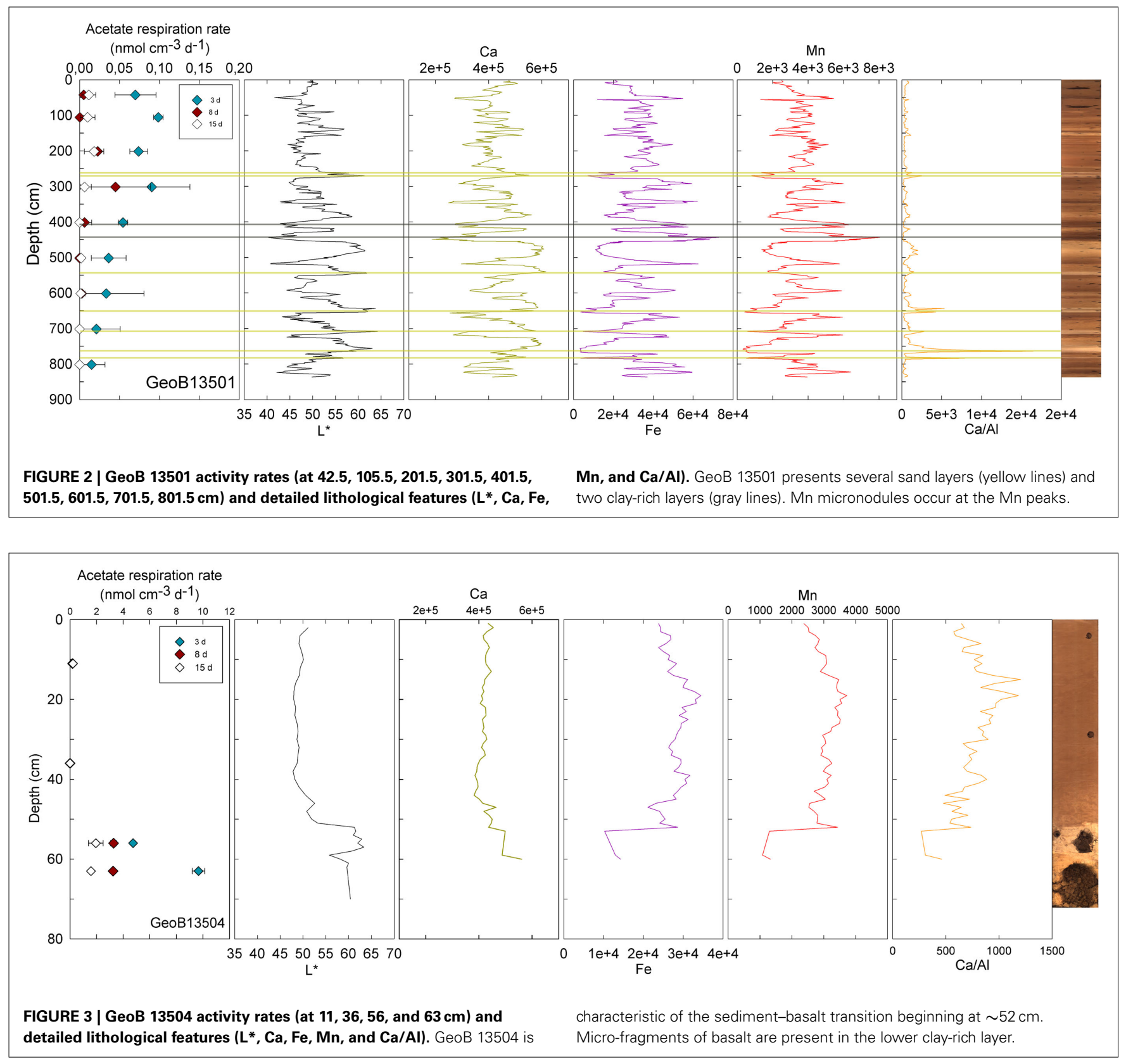

confirmed by $\mathrm{Mn}$ and Fe maxima. In GeoB13504, $\mathrm{L}^{*}$ ranged from 47.86 to 63.41 (Figure 3 ). L* increased abruptly at the transition $(\sim 55 \mathrm{~cm})$ between the nannofossil ooze and the putative dense clay layer. $\mathrm{Ca}$ and thus carbonate content increased while $\mathrm{Fe}$ and $\mathrm{Mn}$ decreased. However the $\mathrm{Ca} / \mathrm{Al}$ ratio decreased significantly at the transition, confirming the presence of very fine-grained sediment which may overlie basalt.

\section{POTENTIAL RESPIRATION RATES IN DEEP-OXIC SUB-SEAFLOOR SEDIMENTS}

Acetate concentrations were below the detection limit $(3 \mu \mathrm{M})$. However, potential microbial heterotrophic activity (as measured by the oxidation of ${ }^{14} \mathrm{C}$-acetate to ${ }^{14} \mathrm{CO}_{2}$ ) was detected in sediment samples recovered from all 14 stations. In all of the samples, the highest rate was measured after the shortest incubation time (3 days) except in samples from GeoB13502 and 13510. A sample from core GeoB 13506 was selected to monitor the oxygen concentration in the slurry as a function of time. In this sample, in which the maximal rate was at $0.41 \mathrm{nmol} \mathrm{cm} \mathrm{cm}^{-3} \mathrm{~d}^{-1}$, oxygen was completely depleted only after 20 days. We therefore assumed that most of the slurries remained oxic throughout the experiment. Thus, a switchover to anaerobic respiration after 3 days can be excluded. Overall, most of the experiments yielded low rates of potential activity $\left(<0.2 \mathrm{nmol} \mathrm{cm}^{-3} \mathrm{~d}^{-1}\right)$, consistent with the expected low fluxes of organic matter to the sediments at North Pond.

At three stations, rates of activity were greatest in the samples taken in the upper $80 \mathrm{~cm}: 0.21 \mathrm{nmol} \mathrm{cm}{ }^{-3} \mathrm{~d}^{-1}$ at $57.5 \mathrm{~cm}$ in GeoB13511, up to $1.46 \mathrm{nmol} \mathrm{cm}^{-3} \mathrm{~d}^{-1}$ at $6 \mathrm{~cm}$ in GeoB13510, 
and $10.62 \mathrm{nmol} \mathrm{cm}^{-3} \mathrm{~d}^{-1}$ at $75.5 \mathrm{~cm}$ in GeoB 13512. In contrast, enhanced rates of potential acetate turnover were not restricted to just near the surface at the other seven stations. At GeoB13506 $(131.5 \mathrm{~cm})$, rates reached $0.41 \mathrm{nmol} \mathrm{cm} \mathrm{cm}^{-3} \mathrm{~d}^{-1}$ in a layer that presented subtle color mottling (presumably associated with preserved bioturbation structures). At GeoB13508, peaks in activity were present at depth with rates of up to $0.17(281.5 \mathrm{~cm})$ and $0.21 \mathrm{nmol} \mathrm{cm}{ }^{-3} \mathrm{~d}^{-1}(331.5 \mathrm{~cm})$. Higher rates of potential acetate turnover were located just below and near sandy layers, which are present at $264-265 \mathrm{~cm}$ and $326-344 \mathrm{~cm}$. Another example of increased activity in sandy layer is present in GeoB13507 (Figure 4), where in the sample taken at $718 \mathrm{~cm}$ in the middle of a sand layer $(713-722 \mathrm{~cm})$ activity was up to $7.52 \mathrm{nmol}$ $\mathrm{cm}^{-3} \mathrm{~d}^{-1}$. The increase in activity is even more remarkable in the sample taken at $723.5 \mathrm{~cm}$ just below the sandy layer (up to $\left.12.10 \mathrm{nmol} \mathrm{cm} \mathrm{cm}^{-3} \mathrm{~d}^{-1}\right)$. The deepest sample investigated in GeoB $13507(822.5 \mathrm{~cm})$, which is also situated below a sand layer at $812-814 \mathrm{~cm}$, also showed high rates of potential activity (up to $4.63 \mathrm{nmol} \mathrm{cm}^{-3} \mathrm{~d}^{-1}$ ). At GeoB 13513, the highest rate (up to $1.01 \mathrm{nmol} \mathrm{cm}^{-3} \mathrm{~d}^{-1}$ ) occurred in the sample taken at $159.5 \mathrm{~cm}$, which, as shown in Figure 5, correlated with a relatively distinct peaks in $\mathrm{L}^{*}$, Ca counts and $\mathrm{Ca} / \mathrm{Al}$. In $\mathrm{GeoB} 13502$, the peaks in potential acetate turnover occurred at three layers at depth: 104.5, 604.5 , and $804.5 \mathrm{~cm}$ (Figure 6).

Conversely, enhanced rates of acetate turnover at $104.5 \mathrm{~cm}$ correspond to low $\mathrm{L}^{*}$, and low $\mathrm{Ca} / \mathrm{Al}$ values. Likewise, a slight increase of activity in GeoB13507 (up to $0.99 \mathrm{nmol} \mathrm{cm}^{-3} \mathrm{~d}^{-1}$ ) at $300.5 \mathrm{~cm}$, occurs in one of the darkest layers of the core $\left(\mathrm{L}^{*}\right.$ at $302 \mathrm{~cm}$ is at 41.31). This layer is also associated with the lowest intensity of $\mathrm{Ca}$ and a low $\mathrm{Ca} / \mathrm{Al}$ ratio. This dark layer is also characterized by the presence of Mn micronodules, as confirmed by high Mn contents (data not shown). Finally, at GeoB 13504 (Figure 3) and GeoB13514 (Figure 7), activity peaks occurred in the deepest layers recovered, 56 and $63 \mathrm{~cm}$ and $205.5 \mathrm{~cm}$, respectively. The presence of clay and basalt micro-fragments at the bottom of core 13504 suggests proximity to the basalt. The clay was very light in color and thus the $L^{*}$ value is the highest zone. The high $\mathrm{L}^{*}$ matches a high Ca content up to $60 \mathrm{~cm}$.

Samples taken at 604.5 in GeoB 13514 and at $804.5 \mathrm{~cm}$ in GeoB 13502, high $\mathrm{L}^{*}$ (as well as high $\mathrm{Ca} / \mathrm{Fe}$ ratio) was coincident with enhanced rates of acetate turnover. In the lower parts of cores 13502 and 13514, the sediment became dense and light-colored. Cores 13504, 13514, and 13502 have in common their location at the top of the north-east edge of the pond, the two first being at a water depth of 4096 and $4040 \mathrm{~m}$, respectively, while the latter is at $4250 \mathrm{~m}$ water depth.

\section{DISCUSSION}

North Pond sediments are oligotrophic, nonetheless, our experiments indicate that microbial heterotrophic communities continue to be active in these deeply buried sediments. The communities react immediately to the supply of acetate as substrate, as no lag phase was observed before the oxidation of acetate to carbon dioxide. In our experiments, we added labeled acetate to concentrations of $20 \mu \mathrm{mol} \mathrm{l}^{-1}$. Growth of a specific aerobic acetotrophic (acetate-oxidizing) community can be excluded with a reasonable probability. More likely, heterotrophic communities are present and potentially active at all depths of the sediments sampled. Moreover, the range of potential activities is highly variable on both depth and lateral scales.

Such heterogeneity in potential activity rates over a small area is remarkable in such an oligotrophic environment, where one would expect low activity rates throughout the cores without much variation. Conversely, nitrate and oxygen fluxes at the surface sediment - water interface appear to be similar across all sites (Cruise report MSM 11/1). Some of this variability in potential activity may be linked to the location and water depth of the sites sampled. In three cores, the activity maxima occurred near the surface, where organic matter is younger and expectedly more accessible toward microbial degradation. The location in the pond might thus influence the magnitude of the increase in activity. For example, the three stations with greater near-surface acetate turnover rates follow a crest directed toward the center of the pond. GeoB13511 is at the bottom of the slope at $4445 \mathrm{~m}$ water depth; GeoB13510 is a bit further north on the slope at $4448 \mathrm{~m}$ water depth and GeoB13512 is northern at $4200 \mathrm{~m}$ water depth at the top of the edge. However, these three stations were the only ones where potential activity was greatest near the surface observed in the upper core; otherwise, peaks in potential acetate turnover could be observed at various depths.

While microbial cell counts and activities tend to decrease with increasing depth in the deep anaerobic sub-seafloor (Parkes et al., 1994, 2000), occurrences of enhanced activity in deep anoxic subseafloor layers have been attributed to geochemical reaction zones, e.g., at sulfate-methane transition zones; at fluid or gas-venting sites; or due to thermally driven alteration of organic matter to form acetate or methane (Cragg et al., 1992, 1995; Wellsbury et al., 1997; Parkes et al., 2005). Remarkable case of increases in subseafloor microbial population abundances and activities have also been observed in gas hydrate associated sediments (Cragg et al., 1995, 1996; Wellsbury et al., 2000).

On the other hand, down-core variability in microbial populations and enhanced microbial activities may be more closely related to changes in the lithology. At an open-ocean site of the Equatorial Pacific (site 1226, ODP Leg 201), prokaryotic activity was stimulated within Miocene age diatomaceous-rich layers (Parkes et al., 2005). At this same site, fluctuations in microbial populations have been related to depositional cycles of high organic carbon content linked to Milankovitch cycles (Aiello and Bekins, 2010). The stimulation of microbial activity at interfaces has also been studied in subsurface consolidated sedimentary structures. For example, increased microbial activity was observed in permeable sandstone layers adjacent to low-permeability organic-rich shales (Fredrickson et al., 1997; Krumholz et al., 1997) and was fueled by excess organic acids produced in the shales which diffused into the adjacent sandstone sediments (McMahon and Chapelle, 1991; McMahon et al., 1992; Fredrickson et al., 1997; Krumholz et al., 1997; Fry et al., 2009).

The North Pond sedimentary ecosystem is, at first glance, different from the systems described above. Specifically geochemical measurements indicate the presence of only one electron acceptor, i.e., oxygen (Cruise report MSM 11/1). In such an oligotrophic environment one would assume low rates of activity that decrease with increasing depth. Nevertheless, lithologic variability on a 


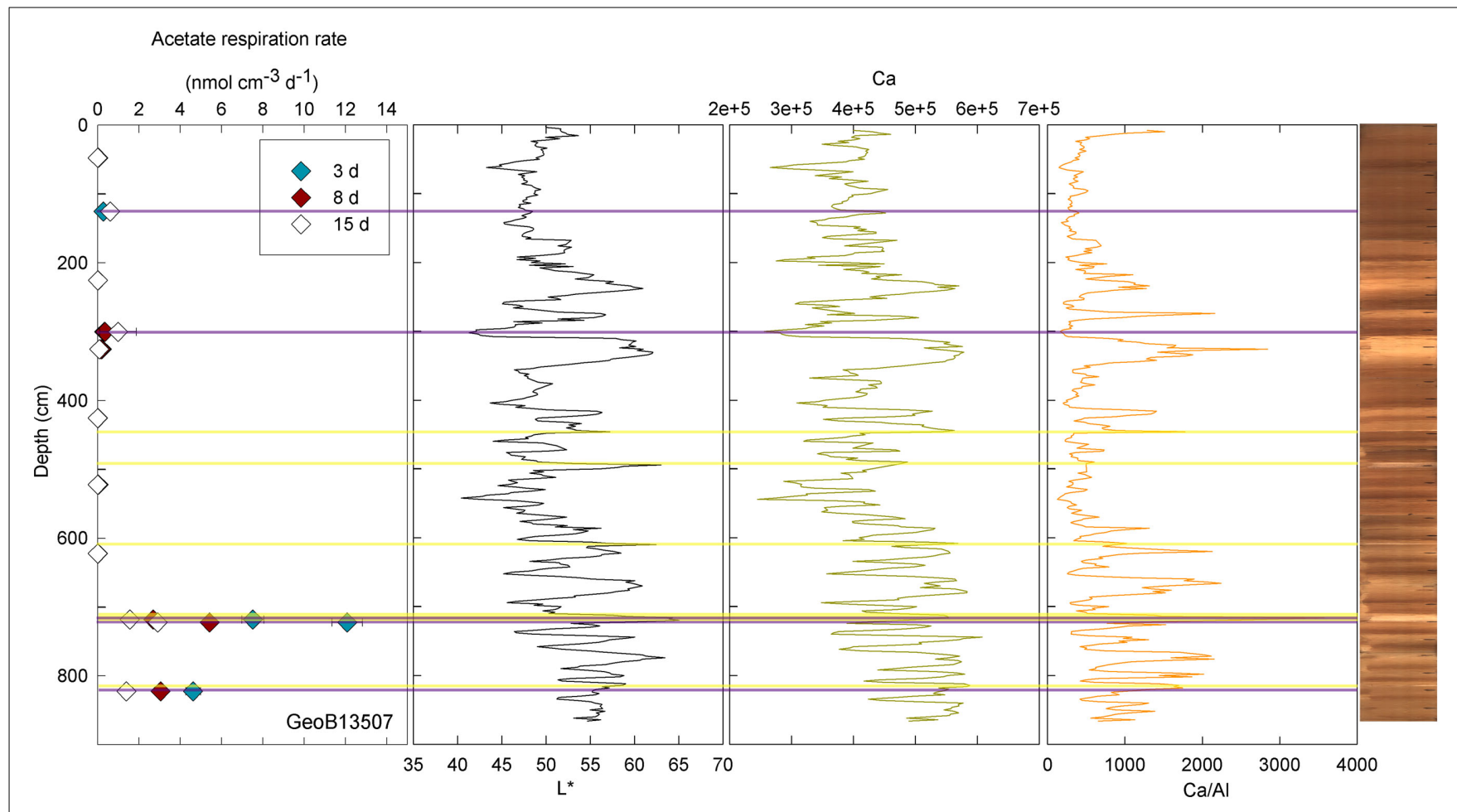

FIGURE 4 | GeoB 13507 linked activities and lithological features. Yellow lines denote sandy layers; purple lines denote depths of greater potential acetate turnover. Samples were taken at 47.5, 125.5, 225.5, 300.5, 325.5, 425.5, 522.5, 622.5, 718, 722.5, and $822.5 \mathrm{~cm}$.

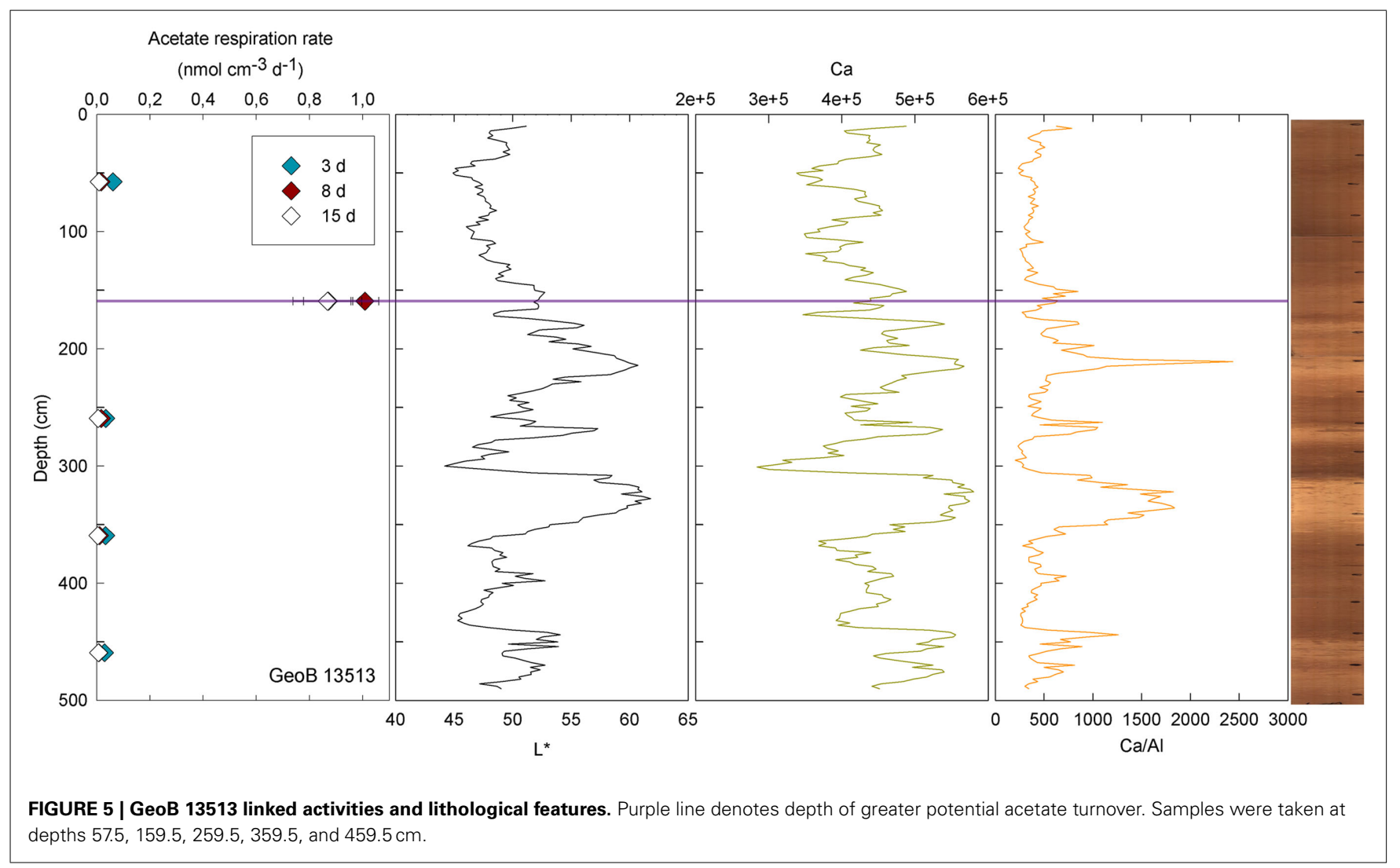






FIGURE 6 | GeoB 13502 linked activities (at 27.5, 104.5, 157, 204.5, 304.5, 404.5, 504.5, 604.5, 704.5, and 804.5 cm) and lithological features (L*, Ca, and $\mathrm{Ca} / \mathrm{Al})$. Yellow lines denote sandy layers; purple lines denote depths of greater potential acetate turnover.




centimeter- to decimeter-scale can be seen throughout all of the examined cores (e.g., color scan figures in Figures 2-7). A link between sediment lithology and potential activity might therefore dictate the variability in the observed rates of potential activity.

We can associate the peaks in potential acetate turnover with three different types of lithology, but no one single lithological type appears to dominate. (1) In cores GeoB13507 and GeoB13508 increased microbial heterotrophic activity can be observed near sandy layers, which are characterized by a high $\mathrm{L}^{*}$ value, a high $\mathrm{Ca}$ content and a high $\mathrm{Ca} / \mathrm{Al}$ ratio. Due to a different permeability, sand layers may be a source of dissolved organic matter that diffuses into the adjacent clay layers, for example as described by Fredrickson et al. (1997) and Krumholz et al. (1997). (2) Other carbonate-rich layers also seem to influence microbial heterotrophic activity in several of the sites cores. In GeoB13506, $13513,13502,13514$, and 13504, increases in activity are also related to relatively high $\mathrm{L}^{*}$ value, $\mathrm{Ca}$ content and $\mathrm{Ca} / \mathrm{Al}$ ratio. At GeoB 13504 the presence of clay indicates the proximity to the basaltic basement. Based on increases with depth of dissolved oxygen (Cruise report MSM 11/1), it is inferred that the basalt is in near proximity at GeoB13514, GeoB 13504, and GeoB13502. Even without the presence of clay at GeoB 13514 and GeoB 13502, it is probable that the basal part of the retrieved sediment section represents the transition to the clay overlying the basaltic basement. (3) Finally there are occurrences of increased activity in cores 13502 and 13507 at dark layers, presumably containing more clay than the surrounding nannofossil ooze.

The experiments show that heterotrophic microbial communities are active in deeply buried sediments, even in oligotrophic, low-organic carbon flux conditions. Most of the highest rates could be partially correlated with the presence of basalt nearby or directly associated with the presence of sandy layers. This suggests that microbial populations are stimulated near/at geological

\section{REFERENCES}

Aiello, I. W., and Bekins, B. A. (2010). Milankovitch-scale correlations between deeply buried microbial populations and biogenic ooze lithology. Geology 38, 79-82.

Albert, D. B., and Martens, C. S. (1997). Determination of low-molecularweight organic acid concentrations in seawater and pore-water samples via HPLC. Mar. Chem. 56, 27-37.

Cragg, B. A., Harvey, S. M., Fry, J. C., Herbert, R. A., and Parkes, R. J. (1992). Bacterial biomass and activity in the deep sediment layers of the JapanSea, hole 798B. Proc. Ocean Drill. Prog. Sci. Results 127/128, 761-776.

Cragg, B. A., Parkes, R. J., Fry, J. C., Weightman, A. J., Rochelle, P. A., and Maxwell, J. R. (1996). Bacterial populations and processes in sediments containing gas hydrates (ODP Leg 146: Cascadia Margin). Earth Planet. Sci. Lett. 139, 497-507.
Cragg, B. A., Parkes, R. J., Weightman, A. J., Rochelle, P. A., Maxwell, J. R., Kastner, M., Hovland, M., Whiticar, M. J., and Sample, J. C. (1995). The impact of fluid and gas venting on bacterial populations and processes in sediments from the Cascadia Margin accretionary system (sites 888-892) and the geochemical consequences. Proc. Ocean Drill. Prog. Sci. Results 146, 399-411.

D'hondt, S., Rutherford, S., and Spivack, A. J. (2002). Metabolic activity of subsurface life in deep-sea sediments. Science 295, 2067-2070.

D'hondt, S., Spivack, A. J., Pockalny, R., Ferdelman, T. G., Fischer, J. P., Kallmeyer, J., Abrams, L. J., Smith, D. C., Graham, D., Hasiuk, F., Schrum, H., and Stancin, A. M. (2009). Subseafloor sedimentary life in the South Pacific Gyre. Proc. Natl. Acad. Sci. U.S.A. 106, 11651-11656.

Finke, N., and Jorgensen, B. B. (2008). Response of fermentation and sulfate reduction to experimental

layers where lateral transport of fluids can occur and potential substrates can be provided to the microbes residing in the sediments. Nevertheless, we also detected potential rates of acetate turnover in other distinctly different lithological layers.

Thus, while we can not link increased microbial heterotrophic activity to a single, distinct lithological type, this study highlights the importance of a sampling strategy following the basic characteristics of the sediment, such as the color or the light reflectance, in the absence of strong pore water chemical gradients. A highresolution study of the interfaces foraminifer sand/nannofossil ooze and basalt/clay would be of great interest. In the case of deepoxic sediments, in which exposure to the atmosphere is not as critical, the sampling procedure could be dictated by non-destructive core analysis such as those employed in this study.

\section{ACKNOWLEDGMENTS}

The authors would like to thank the captain Klaus Bergmann and the crew of the R/V Maria S. Merian; chief scientist HeinerVillinger, and all participants of the MSM 11/1 cruise. We are particularly thankful to Wolfgang Bach for providing the sediment description, as well as insightful comments; to Verena Heuer for providing the pore water samples for acetate measurements; to Friederike Schmidt-Horn for providing the bathymetry map; and to Wiebke Ziebis for discussion. We thank Gabi Schüßler for the assistance in the lab with the ${ }^{14} \mathrm{CO}_{2}$ diffusion method. This research used data acquired at the XRF Core Scanner Lab at MARUM - Center for Marine Environmental Sciences, University of Bremen, Germany. We are thankful to Vera Lukes for help with digital picture and XRF data acquisition. XRF and light reflectance data are available on www.pangaea.de. Aude Picard was funded through DFG-Research Center/Excellence Cluster "The Ocean in the Earth System" and the Max Planck Society. Cruise MSM 11/1 was funded by the German Science Foundation (DFG).

temperature changes in temperate and Arctic marine sediments. ISME J. 2, 815-829.

Fischer, J. P., Ferdelman, T. G., D'hondt, S., Roy, H., and Wenzhofer, F. (2009). Oxygen penetration deep into the sediment of the South Pacific gyre. Biogeosci. Discuss. 6, 3159-3186.

Fredrickson, J. K., Mckinley, J. P., Bjornstad, B. N., Long, P. E., Ringelberg, D. B., White, D. C., Krumholz, L. R., Suflita, J. M., Colwell, F. S., Lehman, R. M., and Phelps, T. J. (1997). Pore-size constraints on the activity and survival of subsurface bacteria in a Late Cretaceous shalesandstone sequence, northwestern New Mexico. Geomicrobiol. J. 14 183-202.

Fry, J. C., Horsfield, B., Sykes, R., Cragg, B. A., Heywood, C., Kim, G. T., Mangelsdorf, K., Mildenhall, D. C., Rinna, J., Vieth, A., Zink, K.-G., Sass, H., Weightman, A. J., and Parkes, R. J. (2009). Prokaryotic populations and activities in an interbedded coal deposit, including a previously deeply buried section (1.6-2.3 $\mathrm{km}$ ) above (150 Ma basement rock. Geomicrobiol. J. 26, 163-178.

Giosan, L., Flood, R. D., and Aller, R. C. (2002). Paleoceanographic significance of sediment color on western North Atlantic drifts: I. Origin of color. Mar. Geol. 189, 25-41.

Hussong, D. M., Fryer, P. B., Tuthill, J. D., and Wipperman, L. K. (1979). The geological and geophysical setting near DSDP site 395, North Atlantic Ocean. Init. Repts. DSDP 45, 23-37.

Krumholz, L. R., Mckinley, J. P., Ulrich, G. A., and Suflita, J. M. (1997). Confined subsurface microbial communities in Cretaceous rock. Nature 386, 64-66.

Langseth, M. G., Hyndman, R. D., Becker, K., Hickman, S., and Salisbury, M. H. (1984). The hydrogeological regime of isolated sediment ponds in mid-ocean ridges. Init. Repts. DSDP 78B, 825-837. 
McMahon, P. B., and Chapelle, F. H. (1991). Microbial production of organic acids in aquitard sediments and its role in aquifer geochemistry. Nature 349, 233-235.

McMahon, P. B., Chapelle, F. H., Falls, W. F., and Bradley, P. M. (1992). Role of microbial processes in linking sandstone diagenesis with organic rich clays. J. Sediment. Petrol. 62, $1-10$.

Murray, J. W., and Grundmanis, V. (1980). Oxygen consumption in pelagic marine sediments. Science 209, 1527-1530.

Parkes, R. J., Cragg, B. A., Bale, S. J., Getliff, J. M., Goodman, K., Rochelle, P. A., Fry, J. C., Weightman, A. J., and Harvey, S. M. (1994). Deep bacterial biosphere in Pacific ocean sediments. Nature 371, 410-413.

Parkes, R. J., Cragg, B. A., and Wellsbury, P. (2000). Recent studies on bacterial populations and processes in subseafloor sediments: a review. Hydrogeol. J. 8, 11-28.

Parkes, R. J., Webster, G., Cragg, B. A., Weightman, A. J., Newberry, C. J., Ferdelman, T. G., Kallmeyer, J., Jorgensen, B. B., Aiello, I. W., and Fry, J. C. (2005). Deep sub-seafloor prokaryotes stimulated at interfaces over geological time. Nature 436, 390-394.

Phelps, T. J., Hedrick, D. B., Ringelberg, D., Fliermans, C. B., and White, D. C. (1989). Utility of radiotracer measurements for subsurface microbiology studies. J. Microbiol. Methods 9, 15-27.

Purdy, G. M., Rabinowitz, P. D., and Schouten, H. (1979). The midAtlantic ridge at $23^{\circ} \mathrm{N}$. Bathymetry and magnetics. Init. Repts. DSDP 45, 119-128.

Richter, T. O., Van Der Gaast, S., Koster, B., Vaars, A., Gieles, R., De Stigter, H. C., De Haas, H., and Van Weering, T. C. E. (2006). "The Avaatech XRF core scanner: technical description and applications to NE Atlantic sediments," in New Techniques in Sediment Core Analysis, ed. R. G. Rothwell (London: Geological Society), 39-50.

Rogerson, M., Weaver, P. P. E., Rohling, E. J., Lourens, L. J., Murray, J. W., and Hayes, A. (2006). "Colour logging as a tool in high-resolution palaeoceanography," in New Techniques in Sediment Core Analysis, ed. R. G. Rothwell. (London: Geological Society), 99-112.

Süß, J., Engelen, B., Cypionka, H., and andSass, H. (2004). Quantitative analysis of bacterial communities from Mediterranean sapropels based on cultivation-dependent methods. FEMS Microbiol. Ecol. 51, 109-121.

Timofeev, P. P., Varentsov, I. M., Rateev, M. A., and Renngarten, N. V. (1979). Lithology, mineralogy, and geochemistry of upper cenozoic sediments at $23^{\circ} \mathrm{N}$ near the Mid-Atlantic Ridge, drilled on Leg 45. Init. Repts. DSDP 45, 323-347.

Treude, T., Boetius, A., Knittel, K. Wallmann, K., and Jorgensen, B. B. (2003). Anaerobic oxidation of methane above gas hydrates at Hydrate Ridge, NE Pacific Ocean. Mar. Ecol. Prog. Ser. 264, 1-14.

Wellsbury, P., Goodman, K., Barth, T., Cragg, B. A., Barnes, S. P., and Parkes, R. J. (1997). Deep marine biosphere fuelled by increasing organic matter availability during burial and heating. Nature 388 573-576.

Wellsbury, P., Goodman, K., Cragg, B. A., and Parkes, R. J. (2000). The geomicrobiology of deep marine sediments from BlakeRidge containing methane hydrate (sites 994, 995, and 997). Proc. Ocean Drill. Prog. Sci. Results 164, 379-391.

Wirsen, C. O., and Jannasch, H. W. (1974). Microbial transformations of some 14C-labeled substrates in coastal water and sediment. Microb. Ecol. 1, 25-37.

Conflict of Interest Statement: The authors declare that the research was conducted in the absence of any commercial or financial relationships that could be construed as a potential conflict of interest.

Received: 02 October 2011; paper pending published: 20 October 2011; accepted: 08 December 2011; published online: 27 December 2011.

Citation: Picard A and Ferdelman TG (2011) Linking microbial heterotrophic activity and sediment lithology in oxic, oligotrophic sub-seafloor sediments of the North Atlantic Ocean. Front. Microbio. 2:263. doi: 10.3389/fmicb.2011.00263

This article was submitted to Frontiers in Extreme Microbiology, a specialty of Frontiers in Microbiology.

Copyright (C) 2011 Picard and Ferdelman. This is an open-access article distributed under the terms of the Creative Commons Attribution Non Commercial License, which permits non-commercial use, distribution, and reproduction in other forums, provided the original authors and source are credited. 